\title{
Performance and Economic Analysis of Gas Turbine Subsystems for Power Generation in the Niger Delta
}

\author{
Sidum Adumene ${ }^{1, a *}$, Anthony Kpegele Le-ol ${ }^{2, b}$, \\ Barinaadaa Thaddeus Lebele-Alawa ${ }^{2}$ \\ ${ }^{1}$ Department of Marine Engineering, Rivers State University of Science and Technology, \\ Port Harcourt, Nigeria \\ 2Department of Mechanical Engineering, Rivers State University of Science and Technology, \\ Port Harcourt, Nigeria \\ asidum.adumene@ust.edu.ng, le-ol.anthony@ust.edu.ng
}

\section{Keywords: Performance, Energy, Exergy, gas turbine and Cost Evaluation}

\begin{abstract}
In this research work, performance and economic analysis of three units' gas turbine plants in the Niger Delta, Nigeria has been carried out for the period of 18 months. The aim of this study is to assess the energy, exergy and economic behavior of the plants' subsystems. The methodology adopted was the splitting of the system into control volumes to show the inflow and outflow of energy and exergy at different operating conditions. A parametric study was also conducted to evaluate the influence of key decision variables like the load on the plant's subsystem performance. The analysis was done in MATLAB $7.3{ }^{\circledR}$ environment and the results reveals that between the $40 \%-86 \%$ loading of the plant, the energy loss was optimum due to outages and exhaust gas energy waste, with revenue worth of $\$ 14,611,642$ cumulatively, while the irreversibility in the exhaust gas progressively increase as the load increases with an exergy destruction cost rate of $\$ 234.98$ per hour per unit. The combustor shows maximum exergy loss at $44 \%$ load with an exergy destruction cost rate of $\$ 127.87$ per hour per unit, while the power turbine highest exergy destruction cost rate occurred at $73 \%$ load. These key performance indicators provide relevant information on the technical state of the plant for decision-making.
\end{abstract}

\section{Introduction}

Gas turbine performance has improved over the years through technological advancement in solving critical energy need of the society. Gas turbine power plant utilizes the chemical energy from the fuel and air combustion to form mechanical energy. This generated mechanical energy can be utilized to drive rotor dynamic systems such as pumps, compressors, etc. Nigeria as a nation has benefited greatly from the technological advancement in the gas turbine for electricity generation. It was reported by the international energy agency that fossil fuels is the largest world's commercial energy source, which accounts for $65 \%$ of energy supply for the world's electricity and $95 \%$ for the world's transportation system [1]. This trend shows that fossil fuel still provides the higher percentage of the world's energy need.

The concept of energy evaluation of a power plant is on account of the energy generation and consumption of the plant over a given period of time including losses. This considered the procedure for collecting, collating and analyzing available energy-related data, in order to establish the most accurate breakdown of energy consumption for a particular plant operation. It thus provides for a qualitative facility (sub-system) examination to identify opportunities for energy saving or wastage. Energy saving or conservation, help in the process of optimizing system performance in any given power plant. Therefore for a holistic performance improvement, the first and second thermodynamic approach will provide a means of measuring losses in energy processes. Energy based approach is silent in the degradation of energy occurring in the thermodynamic system and does not quantify the usefulness or quality of the heat content in various streams of matter leaving the process as products or waste. The Exergy approach is therefore applied to overcome these shortcomings [2]. 
Sureh et al. [3], reviewed the operating conditions of power plants, and advised that plant optimization will enhance efficient performance against the rate of fossil fuel depletion in recent times. They further suggested the use of energy and exergoeconomic techniques for periodic performance evaluation. Energy audit and feasibility study of Oltchim petrochemical plant in Romania has been done by Watts [4]. The audit established that there was high energy consumption at the plant which could lead to high greenhouse gas emission and operational cost. In Oyedepo et al. [5], an economic based performance evaluation was presented. Their result showed that energy generated within the period have a shortfall range from $4.18 \%$ to $14.53 \%$ as against the acceptance value of $5-10 \%$. They further revealed that $35.7 \%$ energy loss (worth M\$251) was recorded for the period. Emovon et al. [6] presented performance evaluation based on outage cost due to system failure (downtime). Their analysis showed that $46 \%$ power generation loss was recorded, and the plant performed at an average of $54 \%$ of its installed capacity.

Different researchers viewed exergy as available energy which is a quantitative measure of the mechanical work loss in any real thermodynamic system as a result of irreversibility in the system [3]. Ayres et al. [2] define exergy as the maximum amount of work that can be done by a subsystem as it approaches thermodynamic equilibrium with its surroundings by a sequence of reversible processes. Exergy therefore measures the extent to which a system deviates from equilibrium with its environment. Kotas [7] defined exergy of a steady stream as the measure of the maximum amount of work obtainable when the stream is brought from its initial state to the dead state by processes during which the stream may interact only with the environment. Exergy is an expression of the "useful" part of the energy in a stream [7]. The first and second laws of thermodynamic are utilized in the expression of steady stream energy and exergy measurement respectively. The description of the exergy in a stream helps us to locate the waste associated with an energy conversion system.

Lebele-Alawa and Asuo [8] in their work showed the performance trend of a 21.6MW gas turbine based on exergy phenomenon. The result of their analysis revealed that the highest exergy destruction occurs in the combustion chamber, which amounts to about $22.18 \mathrm{MW}$ from measurement on a gas turbine within the tropical zone. Ertesvag et al. [9] showed that gas turbine pressure ratio, gas turbine inlet temperature, steam turbine inlet temperature demonstrated great influence on the exergy performance of a gas turbine combined cycle with pre-combustion $\mathrm{CO}_{2}$ capture system. The analysis further revealed that higher exergy loss occurred in the natural gasfired turbine system when compare with hydrogen-rich fuel fired turbine [9]. Kwambai [10] identified subsystems where substantial exergy loss occurred. They include steam transmission units, turbine unit, condenser, and gas ejector unit. The loss in the condenser was rated highest in their analysis, and this was due to the limitation of the wetness of the exhaust system [10]. Verkhivker and Kosoy [11] showed that three fundamental processes that cause exergy destruction in power generation system include combustion process, heating of working fluid and heat exchange process in the heat exchanger unit. Anheden [12] investigated the possibilities of exergy loss reduction in the combustor using chemical looping combustion technique. The result of the investigation showed that the use of nickel oxide in place of oxygen decreases the combustion exergy loss and increase power generation efficiency [12].

Yildirim and Gungor [13] studied the exergoeconomic analysis of cogeneration systems by using cost-based information. They were able to locate areas that needed improvement. They used the specific exergy costing method to carry out their analysis. Ebadi and Gorgi -Bandy [14] found that increasing the turbine inlet temperature increases the exergetic efficiency of a case study 116MW gas turbine plant at Mahshahr-Iran. Sue and Chuang [15] investigated combined cycle power plant exergy efficiency at partial load and variable compressor inlet temperature and fuel temperature. The analysis revealed that the plant power output increases as the inlet air temperature decrease and at 50\% load, the combined cycle power plant exergy load was three times that of $100 \%$ load due to lower steam pressure in the heat recovery steam generator [15].

Adumene [16] conducted a load based exergy analysis of an offshore gas turbine power plant in Nigeria. The result shows that the plant thermal efficiency and exergy efficiency drop by $0.17 \%$ 
and $0.25 \%$, for every $1 \%$ drop in the operational load. It further indicated that the exhaust gas has the highest exergy destruction. According to Adumene et al. [17] showed that decrease in the ambient temperature of a gas turbine plant within the tropical zone from $31^{\circ} \mathrm{C}$ to $18^{\circ} \mathrm{C}$ improved energy performance of the plant by about $0.78 \%$. Kanoglu et al. [18] did an extensive review of works on exergoeconomic analysis as applied to various engineering systems. They concluded that application of the various exergoeconomic methods reviewed could ensure effective utilization of energy resources in thermal systems for sustainable development.

In spite of the fact that energy losses are inevitable in any energy transformation process, every producer, engineer, investor, and decision maker would like to maintain the desired efficiency in the operation of power plant. In the light of the foregoing, this research provides methodologies to assess the performance trend of an energy conversions system, such as the gas turbine plant and its utilization, to promote energy efficient and ways to optimize performance. It considered an evaluation of a $64.8 \mathrm{MW}$ natural gas-fired thermal plant by an economic based energy and exergy assessment of the plant subsystems. An Energy-based performance and an exergetic degradation or loss rate for the subsystems at different plant load and operating conditions were used for the analysis. The economic model based on losses and the respective costs associated with the operational performance of the plant based on the key performance indices were investigated. This is aimed to provide a holistic decision-making framework for energy decision and policy makers. The assessment was carried out between $40 \%-86 \%$ loading of the plant at units A to C, considering the prevailing operating environment. The study area is the South-South zone of Nigeria which lies between latitudes $4^{0} \mathrm{~N}$ and $6^{\circ} \mathrm{N}$, and longitude $5^{0} \mathrm{E}$ and $8^{0} \mathrm{E}$ [19]. The vegetation of the area is an equatorial rain forest. There are basically two seasons- the wet (April to September) and the dry (October to March) [19]. However, rain falls throughout the year. The mean annual rainfall in the area is between $200 \mathrm{~mm}$ in the North and $400 \mathrm{~mm}$ in the South of the region and the mean daily temperature of the region varies slightly from $27^{0} \mathrm{C}$ to $30^{\circ} \mathrm{C}$ all year round [19]. The maximum and minimum temperatures are $40^{\circ} \mathrm{C}$ and $20^{\circ} \mathrm{C}$ respectively. The relative humidity varies between a minimum of $50 \%$ and a maximum of $90 \%[8,19]$.

\section{Methods and numerical models}

MS5001 gas turbine plant of three $21.6 \mathrm{MW}$ (that is $64.8 \mathrm{MW}$ ) capacity operating on an open cycle was used as the test engine for about 18 months. The plant was monitored and data collected from the human machine interface (HMI). Design values were collected from the installation document of the plant. The thermodynamic relations and equations were used for the phenomenon that could not be directly measured and analysis was done in MATLAB $7.3^{\circledR}$ environment. For the purpose of this analysis, we used the mean values of daily operating parameters of the plants. The methodology adopted was designed to produce facts about the behavior of the plant and to determine key factors that influence the energy and exergy based analysis of the plant aimed at evaluating its performance. Economic models were used to evaluate the cost based optimization of the plant.

\section{Energy Balance for Gas Turbine System}

The analytical technique used to perform energy balance on an engineering system is the conservation of energy principle which is expressed as:

Total Energy Entering the System -Total Energy Leaving the System = Change in the Total Energy of the System

$$
E_{\text {in }}-E_{\text {out }}=\Delta E_{\text {system }}
$$

The mechanism of energy transfer to or from the system should be well understood before performing the analysis since three forms of energy transfer exist (heat, works and mass flow). 
Therefore we have

$$
E_{\text {in }}-E_{\text {out }}=\left(Q_{\text {in }}-Q_{\text {out }}\right)+\left(W_{\text {in }}-W_{\text {out }}\right)+\left(E_{\text {mass }, \text { in }}-E_{\text {mass }, \text { out }}\right)=\Delta E_{\text {system }}
$$

The energy balance for the compressor is

$$
\dot{E}_{\text {in }}-\dot{E}_{\text {out }}=\frac{d E_{c v}}{d t}
$$

For steady flow system $\dot{E}_{\text {in }}-\dot{E}_{\text {out }}=0$.

The energy balance for the combustor is given by

$$
Q_{\text {in }}=\dot{m}_{e}\left(h_{3}-h_{2}\right)=\left(\dot{m}_{a}+\dot{m}_{f}\right) \times c_{p a}\left(T_{3}-T_{2}\right)=\dot{m}_{f} \times C V
$$

where $\dot{m}_{a}$ is the mass flow rate of air, $\dot{m}_{f}$ is the mass flow rate of fuel, $c_{p a}$ is the specific heat capacity of air, and $C V$ is the calorific value of the fuel. To get $T_{3}$ for a different fixed amount of fuel supply at each $T_{1}$, it was therefore necessary to extrapolate.

For steady flow- steady state condition, the extrapolated function is given by [19],

$$
E T=C E T+(A T T I-C E T)(F F S / A F S)
$$

where ET is the extrapolated temperature, K, CET is the compressor exit temperature, $\mathrm{K}$, ATTI is the actual temperature at turbine inlet for actual fuel supply, $\mathrm{K}, F F S$ is fixed fuel supply, $\mathrm{m}^{3} / \mathrm{s}, A F S$ is actual fuel supply, $\mathrm{m}^{3} / \mathrm{s}$.

The performance of the plant was therefore assessed by the determination of its thermal efficiency. That is

$$
\eta_{t h}=\frac{\text { Net } \text { workoutput }}{\text { Heat Supplied }}=\frac{\dot{W}_{\text {net }}}{Q_{\text {in }}}
$$

where $\dot{W}_{n e t}=W_{T}-W_{C}$.

Similarly, the performance of the plant can also be assessed by the use of energy efficiency which is defined as

$$
\eta_{E}=\frac{\text { Useful Energy Output }}{\text { Energy Input }}=\frac{\text { Net Electrical Energy }}{\dot{m}_{f} \times \text { Energy Content of fuel }(\mathrm{CV})}
$$

Back Work Ratio is another performance indicator for a power plant. It is defined as the ratio of the compressor work input to turbine work output [20]

$$
r_{b w}=\frac{W_{C, a c t}}{W_{T, a c t}}
$$

\section{Energoeconomic Analysis}

The energy based economic indices used in this work include:

Plant Generating Capacity (PGO): This refers to both the total amount of power (GW) and energy $(\mathrm{GWh})$ the plant is capable of producing on site, where the energy generating capacity (EGC) equals the power generating capacity (PGO) multiplied by the actual running hours

$$
E G C=P G C_{G W} \times \text { Running Hours } \text { H }_{H}
$$

where EGC is the energy generating capacity and PGC is the power generating capacity. 
Capacity Factor (CF): The extent of use of the generating plant is measured by the capacity factor, which is the ratio of the average energy output of the plant for a given period of time to the plant capacity. This gives the ratio of the average load to the rated capacity of the plant

$$
C F=\frac{E_{g}}{C_{\text {in }} \times T_{h}}
$$

where $E_{g}$ is the total energy generated $(\mathrm{GWh})$ in a given period, $\mathrm{C}_{\mathrm{in}}$ is the installed capacity of the plant, and $\mathrm{T}_{\mathrm{h}}$ is the total hours of the year.

Plant Use Factor: This is the ratio of actual energy generated during a given period to the design capacity of the plant and the number of hours the plant has been in operation during the period. This is a modification of plant capacity factor in that only the actual number of hours that the plant was in operation is used.

$$
P U F=\frac{E_{g}}{C_{\text {in }} \times T_{\text {oh }}}
$$

where $T_{\mathrm{oh}}$ is the total number of operating hours for the given period.

\section{Exergy Balance for Gas Turbine System}

Real natural gas-fired power plants are steady flow open circuit systems in which fuel and oxidant (usually air) are supplied to the combustor of the plant and the products of combustion are exhausted to the atmosphere. The general control volume for such thermodynamic system is shown below [21].

The first law of thermodynamic for the control volume can be written as

$$
\frac{d E_{c r}}{d t}=\dot{m}_{i}\left(h_{i}+\frac{V_{i}^{2}}{2}+g Z_{i}\right)-\dot{m}_{e}\left(h_{i}+\frac{V_{i}^{2}}{2}+g Z_{i}\right)+Q_{o}+\sum_{j=1}^{m} Q_{j}-W
$$

The second law of thermodynamic for the control volume [21] is

$$
\frac{d S_{c r}}{d t}=\dot{m}_{i} s_{i}-\dot{m}_{e} s_{e}+\frac{\dot{Q}_{o}}{T_{o}}+\sum_{j=1}^{m} \frac{\dot{Q}_{j}}{T_{j}}+\dot{S}_{g e n}
$$

For a steady state flow process at constant kinetic and gravitational potential energy, we have

$$
\dot{W}=T_{o}\left(\dot{m}_{e} s_{e}-\dot{m}_{i} s_{i}\right)+\dot{m}_{i} h_{i}-\dot{m}_{e} h_{e}-\sum_{j=1}^{m}\left(\frac{\dot{Q}_{j}}{T_{j}}\right) T_{o}+\sum_{j=1}^{m} \dot{Q}_{j}-T_{o} \dot{S}_{g e n}
$$

The term of exergy transfer by heat may be difficult to evaluate the values of $\dot{Q}_{j}$ and $T_{j}$ are not known at every position on the boundary of the control volume [22]. To cushion the ensuing deficiency, Wark and Richard [22] suggest that the variable surface temperature $T_{j}$ should be replaced by a constant boundary temperature $T_{b}$.

\section{Exergoeconomic Analysis}

Kwak et al [23] levelized cost method is applied to the plant component. The amortization cost for such components is given as

$$
P W=C_{i}-S_{n} \times P W F(i, n)
$$

where $C_{i}(\$)$ is the investment cost which is solely the $P E C, S_{n}(\$)$ is the salvage value at the nth year taken as zero. The present worth of the component may be converted to the annualized cost by using the capital recovery factor, $C R F(i, n)$, given as

$$
C(\$ / y r)=P W \times C R F(i, n)
$$


The period of consideration is 18 months with operating hours of 6000 ; therefore, the leveled capital cost rate for the kth component of the plant gives

$$
\dot{Z}_{k}=\frac{\emptyset_{k} \dot{C}_{k}}{A}
$$

where $A=3600 \times 6000=21600000(s)$ and $\emptyset_{k}$ is the maintenance factor.

Hence for both costs and the associated exergy of streams and components gives

$$
\sum_{i}\left(c_{i} \dot{E}_{i}\right)_{k}+c_{q, k} \dot{E}_{q, k}+\dot{Z}_{k}=\sum_{e}\left(c_{e} \dot{E}_{e}\right)_{k}+c_{w, k} \dot{W}_{k}
$$

The last equation shows that the sum of cost rates associated with all entering streams plus the financial charge associated with owning and operating the $\mathrm{k}_{\text {th }}$ plant component equals the sum of all exergy of the exiting streams. The specific cost of fuel and product per unit exergy of any component $\mathrm{k}$ are respectively given as

$$
C_{f, k}=\frac{\dot{C}_{f u e l, k}}{\dot{E}_{f u e l, k}}
$$

and

$$
C_{p, k}=\frac{\dot{C}_{\text {product }, k}}{\dot{E}_{\text {product }, k}}
$$

The cost rate of exergy destroyed in any component $\mathrm{k}[13]$ is

$$
\dot{C}_{D, k}=c_{f, k} I_{D, k}
$$

\section{Results and Discussion}

The plant has 3 units of $21.6 \mathrm{MW}$. The analysis takes an overview of the entire systems for the 3 units of the power plant. Tables 2-4 show the result of the energy analysis of the plant, while Tables 5-7 indicate the exergy analysis. 
Table 1. Design, Economic, and Average Operational Data.

\begin{tabular}{|c|c|c|c|c|c|}
\hline Parameters & Units & Design Value & Unit A & Unit B & Unit C \\
\hline Installed capacity & MW & 21.6 & & & \\
\hline Power generated & MW & - & 11 & 12 & 12.2 \\
\hline Inlet temperature & $\mathrm{K}$ & - & 300.5 & 300.6 & 300.8 \\
\hline Discharge temperature & K & - & 580.2 & 576.5 & 585.4 \\
\hline Turbine inlet temperature & $\mathrm{K}$ & - & 1004.97 & 1053.88 & 1061.66 \\
\hline Exhaust temperature & K & - & 644 & 646 & 582.2 \\
\hline Lube oil temperature & $\mathrm{C}$ & - & 52 & 52 & 51 \\
\hline Drain temperature & $\mathrm{C}$ & - & 92.8 & 90.4 & 92.4 \\
\hline Inlet pressure & bar & - & 1.013 & 1.013 & 1.013 \\
\hline Discharge pressure & bar & - & 7.1 & 7 & 7.2 \\
\hline Fuel inlet pressure & bar & - & 11.41 & 11.42 & 11.44 \\
\hline Turbine inlet pressure & bar & - & 7.1 & 7 & 7.2 \\
\hline Exhaust pressure & bar & - & 1.013 & 1.013 & 1.013 \\
\hline Air flow rate & $\mathrm{kg} / \mathrm{s}$ & 109.7 & 96.17 & 102.38 & 102.38 \\
\hline Fuel flow rate & $\mathrm{kg} / \mathrm{s}$ & 1.7 & 0.83 & 0.61 & 0.88 \\
\hline Exhaust flow rate & $\mathrm{kg} / \mathrm{s}$ & 111.4 & 97 & 102.99 & 103.99 \\
\hline Inlet guide vane & $\%$ & 100 & 88 & 93 & 93 \\
\hline Stop ratio valve & $\%$ & - & 36.56 & 43.5 & 39.24 \\
\hline Gas control valve & $\%$ & - & 48.71 & 35.81 & 51.54 \\
\hline Energy Cost per kWh & $\$$ & 0.076 & - & - & - \\
\hline Exergy Cost per GJ & $\$$ & 3.58 & - & - & - \\
\hline Plant Analysis Period & months & 18 & - & - & - \\
\hline Plant Operating Hours & $\mathrm{hr}$ & 6000 & - & - & - \\
\hline
\end{tabular}


Table 2. Energoeconomic Characteristics of the Power Plant at unit A.

\begin{tabular}{|c|l|c|c|c|c|c|}
\hline $\begin{array}{c}\text { \%o } \\
\text { Loading }\end{array}$ & \multicolumn{1}{|c|}{ Components } & $\begin{array}{c}\text { Rate of } \\
\text { Energy } \\
\text { Losses } \\
\text { (MW) }\end{array}$ & $\begin{array}{c}\text { Plant } \\
\text { Generated } \\
\text { Output } \\
\text { (PGO) (MW) }\end{array}$ & $\begin{array}{c}\text { Thermal } \\
\text { Efficiency }\end{array}$ & $\begin{array}{c}\text { Energy } \\
\text { Generated } \\
\text { (EGC)/Losses } \\
\text { (GWh) }\end{array}$ & $\begin{array}{c}\text { Cost Rate } \\
\text { of Energy } \\
\text { Wastage } \\
\text { (\$/hr) }\end{array}$ \\
\hline $40 \%$ & Energy input 9.42MW & - & 9.50 & $24.10 \%$ & 57.00 & - \\
\hline & Gearbox and generator & 0.15 & - & - & 0.90 & 67,905 \\
\hline & Gas turbine cooling & 10.69 & - & - & 64.14 & $4,839,363$ \\
\hline & Exhaust gas & 19.08 & - & - & 114.50 & $8,639,025$ \\
\hline $51 \%$ & Energy input 41.42MW & - & 11.00 & $26.56 \%$ & 66.00 & - \\
\hline & Gearbox and Generator & 0.17 & - & - & 1.00 & 75,450 \\
\hline & Gas turbine cooling & 7.45 & - & - & 44.70 & $3,372,615$ \\
\hline & Exhaust gas & 22.80 & - & - & 136.80 & $10,321,560$ \\
\hline
\end{tabular}

Table 3. Energoeconomic Characteristics of the Power Plant at Unit B.

\begin{tabular}{|c|c|c|c|c|c|c|}
\hline $\begin{array}{c}\% \\
\text { Loading }\end{array}$ & Components & $\begin{array}{l}\text { Rate of } \\
\text { Energy } \\
\text { Losses } \\
\text { (MW) }\end{array}$ & $\begin{array}{c}\text { Plant } \\
\text { Generated } \\
\text { Output } \\
\text { (PGO) (MW) }\end{array}$ & $\begin{array}{l}\text { Thermal } \\
\text { Efficiency }\end{array}$ & $\begin{array}{c}\text { Energy } \\
\text { Generated } \\
\text { (EGC)/ } \\
\text { Losses } \\
\text { (GWh) }\end{array}$ & $\begin{array}{c}\text { Cost Rate } \\
\text { of Energy } \\
\text { Wastage } \\
\text { (\$/hr) }\end{array}$ \\
\hline \multirow[t]{4}{*}{$44 \%$} & Energy input $26.95 \mathrm{MW}$ & - & 9.6 & $35.62 \%$ & 57.6 & - \\
\hline & Gearbox and Generator & 0.15 & - & - & 0.9 & 67,905 \\
\hline & Gas turbine cooling & 7.41 & - & - & 44.5 & $3,357,525$ \\
\hline & Exhaust gas & 9.79 & - & - & 58.7 & $4,428,915$ \\
\hline \multirow[t]{4}{*}{$73 \%$} & Energy input $36.08 \mathrm{MW}$ & - & 15.7 & $43.51 \%$ & 94.2 & - \\
\hline & Gearbox and Generator & 0.25 & - & - & 1.5 & 113,175 \\
\hline & Gas turbine cooling & 6.76 & - & - & 40.56 & $3,060,252$ \\
\hline & Exhaust gas & 13.13 & - & - & 78.78 & $5,943,951$ \\
\hline \multirow[t]{4}{*}{$85 \%$} & Energy input $36.13 \mathrm{MW}$ & - & 15.9 & $44.01 \%$ & 95.4 & - \\
\hline & Gearbox and Generator & 0.25 & - & - & 1.5 & 113,175 \\
\hline & Gas turbine cooling & 6.25 & - & - & 37.5 & $2,829,375$ \\
\hline & Exhaust gas & 13.44 & - & - & 80.64 & $6,084,288$ \\
\hline
\end{tabular}


Table 4. Energoeconomic Characteristics of Power Plant at Unit C.

\begin{tabular}{|c|c|c|c|c|c|c|}
\hline $\begin{array}{c}\% \\
\text { Loading }\end{array}$ & Components & $\begin{array}{l}\text { Rate of } \\
\text { Energy } \\
\text { Losses } \\
\text { (MW) }\end{array}$ & $\begin{array}{c}\text { Plant } \\
\text { Generated } \\
\text { Output(PGO) } \\
\text { (MW) }\end{array}$ & $\begin{array}{l}\text { Thermal } \\
\text { Efficiency }\end{array}$ & $\begin{array}{c}\text { Energy } \\
\text { Generated } \\
\text { (EGC)/ } \\
\text { Losses } \\
\text { (GWh) }\end{array}$ & $\begin{array}{c}\text { Cost Rate } \\
\text { of Energy } \\
\text { Wastage } \\
(\$ / h r)\end{array}$ \\
\hline \multirow[t]{4}{*}{$46 \%$} & Energy input 39.42MW & - & 10.4 & $26.38 \%$ & 62.4 & - \\
\hline & Gearbox and Generator & 0.16 & - & - & 0.96 & 72,432 \\
\hline & Gas turbine cooling & 7.60 & - & - & 45.6 & $3,440,520$ \\
\hline & Exhaust gas & 21.26 & - & - & 127.56 & $9,624,402$ \\
\hline \multirow[t]{4}{*}{$56 \%$} & Energy input $43.91 \mathrm{MW}$ & - & 12.2 & $27.78 \%$ & 73.2 & - \\
\hline & Gearbox and Generator & 0.19 & - & - & 1.14 & 86,013 \\
\hline & Gas turbine cooling & 7.56 & - & - & 45.36 & $3,422,412$ \\
\hline & Exhaust gas & 23.96 & - & - & 143.76 & $10,846,692$ \\
\hline \multirow[t]{4}{*}{$86 \%$} & Energy input $57.84 \mathrm{MW}$ & - & 18.5 & $31.99 \%$ & 111 & - \\
\hline & Gearbox and Generator & 0.29 & - & - & 1.74 & 131,283 \\
\hline & Gas turbine cooling & 6.94 & - & - & 41.64 & $3,141,738$ \\
\hline & Exhaust gas & 32.11 & - & - & 193.66 & $14,611,647$ \\
\hline
\end{tabular}

The expected full load installed capacity of the plant for the period under study is $129.6 \mathrm{GW}$ per unit, but the generated capacity for the period on an average is $82.4 \mathrm{GW}$. This shows a reduction in the installed capacity and the actual operational capacity. Factors like environment, age, losses and poor maintenance culture may be responsible for the shortfall. The result in Table 4 indicates the trending of the plant performance at different loading conditions. The plant production capacity and power drop for the period were analyzed. The result show that as the production capacity increases the power drop decreases and the plant load increases. It means that as the production capacity increases by $1 \%$, the power drop decreases by about $0.22 \%$, with a proportional increase in loading. Further analysis shows that the cost rate of energy wasted reduces by $\$ 97,775.34$ for the plant under review. This is an indication that the plant can be economically optimized by reducing energy drop for the period through sustainable energy generation. The full capacity operation of the plant under favorable conditions brings in an optimum investment returns and energy production. 
Table 5. Exergoeconomic Characteristics of the Power Plant at Unit A.

\begin{tabular}{|c|l|c|c|c|c|c|}
\hline $\begin{array}{c}\text { \%o } \\
\text { Loading }\end{array}$ & \multicolumn{1}{|c|}{ Components } & $\begin{array}{c}\text { Rate of } \\
\text { Exergy } \\
\text { Losses } \\
(\mathbf{M W})\end{array}$ & $\begin{array}{c}\text { Useful } \\
\text { Exergy } \\
\mathbf{( M W )}\end{array}$ & $\begin{array}{c}\text { Exergetic } \\
\text { Efficiency }\end{array}$ & $\begin{array}{c}\text { Exergy } \\
\text { Utilized/ } \\
\text { Destroyed } \\
\mathbf{( G W h )}\end{array}$ & $\begin{array}{c}\text { Cost Rate } \\
\text { destroyed } \\
\mathbf{( \$ / h r )}\end{array}$ \\
\hline $44 \%$ & Exergy input 44.04MW & - & 9.50 & $21.57 \%$ & 57.00 & - \\
\hline & Compressor & 2.14 & - & - & 12.84 & 45.97 \\
\hline & Combustor & 20.54 & - & - & 123.24 & 441.20 \\
\hline & Power turbine & 1.59 & - & - & 9.24 & 33.08 \\
\hline & Gearbox and generator & 0.15 & - & - & 0.90 & 3.22 \\
\hline & Exhaust gas & 10.12 & - & - & 60.72 & 217.38 \\
\hline $52 \%$ & Exergy input 46.26MW & - & 11.20 & $24.21 \%$ & 67.20 & - \\
\hline & Compressor & 3.1 & - & - & 18.60 & 66.59 \\
\hline & Combustor & 18.37 & - & - & 110.22 & 398.17 \\
\hline & Power turbine & 2.12 & - & - & 12.72 & 45.54 \\
\hline & Gearbox and generator & 0.18 & - & - & 1.08 & 3.87 \\
\hline & Exhaust gas & 11.29 & - & - & 67.74 & 242.51 \\
\hline
\end{tabular}

Table 6. Exergoeconomic Characteristics of the Power Plant at Unit.

\begin{tabular}{|c|l|c|c|c|c|c|}
\hline $\begin{array}{c}\text { \%o } \\
\text { Loading }\end{array}$ & \multicolumn{1}{|c|}{ Components } & $\begin{array}{c}\text { Rate of } \\
\text { Exergy } \\
\text { Loss } \\
\mathbf{( M W )}\end{array}$ & $\begin{array}{c}\text { Useful } \\
\text { Exergy } \\
\mathbf{( M W )}\end{array}$ & $\begin{array}{c}\text { Exergetic } \\
\text { Efficiency }\end{array}$ & $\begin{array}{c}\text { Exergy } \\
\text { Utilised/ } \\
\text { Destroyed } \\
(\mathbf{G W h})\end{array}$ & $\begin{array}{c}\text { Cost Rate } \\
\text { Destroyed } \\
\text { (\$/hr) }\end{array}$ \\
\hline $56 \%$ & Exergy input 34.00MW & - & 12 & $35.29 \%$ & 72 & - \\
\hline & Compressor & 3.34 & - & - & 20.04 & 71.74 \\
\hline & Combustor & 4.12 & - & - & 24.72 & 88.50 \\
\hline & Power turbine & 2.05 & - & - & 12.30 & 44.03 \\
\hline & Gearbox and generator & 0.19 & - & - & 1.14 & 4.08 \\
\hline & Exhaust gas & 12.3 & - & - & 73.80 & 264.20 \\
\hline & & & & & & \\
\hline & Exergy input 40.36MW & - & 15.9 & $38.95 \%$ & 95.4 & - \\
\hline & Compressor & 3.47 & - & - & 20.82 & 74.54 \\
\hline & Combustor & 2.94 & - & - & 17.64 & 63.15 \\
\hline & Power turbine & 2.16 & - & - & 12.96 & 46.40 \\
\hline & Gearbox and generator & 0.25 & - & - & 1.50 & 5.37 \\
\hline & Exhaust gas & 15.64 & - & - & 93.84 & 335.95 \\
\hline
\end{tabular}


Table 7. Exergoeconomic Characteristics of the Power Plant at Unit C.

\begin{tabular}{|c|l|c|c|c|c|c|}
\hline $\begin{array}{c}\text { Loading } \\
\text { Lomponents }\end{array}$ & $\begin{array}{c}\text { Rate of } \\
\text { Exergy } \\
\text { Loss } \\
\mathbf{( M W )}\end{array}$ & $\begin{array}{c}\text { Useful } \\
\text { Exergy } \\
\mathbf{( M W )}\end{array}$ & $\begin{array}{c}\text { Exergetic } \\
\text { Efficiency }\end{array}$ & $\begin{array}{c}\text { Exergy } \\
\text { Utilized/ } \\
\text { Destroyed } \\
\text { (GWh) }\end{array}$ & $\begin{array}{c}\text { Cost Rate } \\
\text { Destroyed } \\
\text { (\$/hr) }\end{array}$ \\
\hline $46 \%$ & Exergy input 49.04MW & - & 10 & $20.39 \%$ & 60.00 & - \\
\hline & Compressor & 2.92 & - & - & 17.52 & 62.72 \\
\hline & Combustor & 17.31 & - & - & 103.86 & 371.82 \\
\hline & Power turbine & 1.50 & - & - & 9.00 & 32.22 \\
\hline & Gearbox and generator & 0.16 & - & - & 0.96 & 3.44 \\
\hline & Exhaust gas & 12.15 & - & - & 72.90 & 260.98 \\
\hline $85 \%$ & Exergy input 64.46MW & - & 18.3 & $28.39 \%$ & 109.20 & - \\
\hline & Compressor & 3.47 & - & - & 20.82 & 74.54 \\
\hline & Combustor & 19.2 & - & - & 115.20 & 412.42 \\
\hline & Power turbine & 3.12 & - & - & 18.72 & 67.02 \\
\hline & Gearbox and generator & 0.29 & - & - & 1.74 & 6.23 \\
\hline & Exhaust gas & 20.08 & - & - & 120.48 & 431.32 \\
\hline
\end{tabular}

The investigation also revealed the energy generated and their percentage losses in the plant sub-systems. It indicates that the exhaust gas energy losses progressively increased between 44$56 \%$ loading, with maximum loss occurring at the $86 \%$ load. The cost implication of the energy loss was about $\$ 14,611,642$ when the plant is operating at $86 \%$ load. The energy wasted in the exhaust gas can be utilized for effective work or heating process. Optimizing this plant may consider the reduction of energy in the exhaust gas. The exergy analysis as indicated in Tables 5-7 shows the trend of exergy destruction and utilization within the plant sub-systems. The exergy wasted in the various components of the plant at different loading conditions and its cost implications were evaluated. The result shows that the irreversibility in the exhaust gas progressively increased as the load increases. The cost rate of the exergy destroyed in the exhaust per hour gives about $\$ 234.98$ economic waste. This can be effectively reduced to enhance the plant better investment return. The combustor shows a maximum cost rate of exergy loss of $\$ 127.87$ at $44 \%$ operational load. The exergy destroyed in the power turbine have the highest cost rate of about $\$ 40.59$ per hour at $73 \%$ operational load.

The performance and efficiencies of the plant at various units were combined to evaluate the overall state of the plant. For unit B at $73 \%$ loading and unit $\mathrm{C}$ at $85 \%$ loading, the overall performances is $37.6 \%$. In the combination analysis, the maximum energy based efficiencies occurred when unit B operates at $74 \%$ loading and unit $\mathrm{C}$ at $86 \%$ loading. Similarly, the maximum overall power output occurs when unit A, B, C operates at 51\%, 55.5\%, and 56\% loading respectively. The maximum overall exergy efficiency is recorded when unit $\mathrm{A}, \mathrm{B}, \mathrm{C}$ operates at $52 \%, 52 \%$, and $50 \%$ loading respectively. It therefore revealed that these performance indicators are dependent on the loading condition of the plant. It is necessary as energy professionals to carry out load variation tactically in order to optimize the plant output. The economic implications show a great benefit to the investor when the overall power output is optimum. More so, the incorporation of the HRSG enhances the utilization of the energy in the exhaust gas and reduction in exergy destruction in the exhaust gas. The analysis revealed that about $42.45 \mathrm{MW}$ of heat flow which is usually rejected in the exhaust gas of the thermal power plant could be converted to $12.9 \mathrm{MW}$ of electric power per unit. Therefore the performance optimization revealed the amount of waste energy recovered, which is about $12.9 \mathrm{MW}(77.4 \mathrm{GWh})$ with a corresponding increase in the revenue of energy generated by $\$ 5,882,400$ for the period under consideration. 


\section{Conclusion}

In this study, performance evaluation and economic analysis of gas turbine subsystems for three 21.6MW units have been investigated. Emphasis has been on key performance indices in terms of energy, exergy and cost evaluation. The study revealed that about $82.4 \mathrm{GW}$ per unit of the plant's capacity was available for the period of analysis. Also, the percentage shortfall of energy generated within the period under review was $36.4 \%$. The load factor varied from $40 \%$ to $86 \%$ with an average of $63 \%$ as against the international best practices of $80 \%$ and above. As the energy production increases by $1 \%$, the power drop decreases by about $0.22 \%$ with a proportional increase in load. At an optimum loading of $86 \%$, the plant efficiency was $37.6 \%$ with an enormous energy loss due to outrages and exhaust gas wastages. The average exergy destroyed in the exhaust per hour gives about $\$ 234.98$ economic waste. The performance of the subsystems aggregates to the overall efficiency of the entire plant. The analysis further revealed the cost implication of the energy and exergy wastages and outages in all the subsystems. From the analysis, incorporation of the heat recovery system enhances the utilization of the energy in the exhaust gas and reduces global warming. The wasted energy can be converted into an electrical energy industrial and domestic utilization. However, augmenting the plant with intercooling to an initial operating temperature of $18^{\circ} \mathrm{C}$ increased the power output by $2.096 \mathrm{MW}$. This study shows that the performance of the plant can be greatly improved, and economic waste reduced drastically. This can be sustained by an improved operational, maintenance and management practices. The benefit of using energy and exergy economic tools to understand the efficiencies of thermal plant subsystems and to provide improvement methods to minimize waste has been demonstrated. These performance indicators show a significant role in evaluating the technical and economy state of the thermal power system. They prove useful in such activities to engineer, scientist, investor, decision and policy makers within the energy subsector.

\section{References}

[1] S. Rao, B.B. Parulekar, Energy technology: non-conventional, renewable, and conventional, Third Revised and Updated Edition, Khanna Publishers, Delhi, India, 2007, pp. 13-14

[2] R.U. Ayres, L.W. Ayres, B. Warr, Exergy, power and work in the US economy (1900-1998), Energy. 28(3) (2003) 219-273.

[3] M.V.J.J. Suresh, R.S. Reddy, A. J. Kolar, Energy and exergy based thermodynamic analysis of a 62.5MW Coal-based thermal power plant- A case study, Indian Institute of Technology, Madras, 2006.

[4] Energy Audit at a Romanian Petrochemical Plant, 2001. Available: http://pdf.usaid.gov/pdf_docs/Pnada709.pdf.

[5] S.O. Oyedepo et al., Performance evaluation and economic analysis of a gas turbine plant in Nigeria, Energy Conservation and Management. 79 (2014) 431-440.

[6] I. Emovon, B. Kareem, M. K. Adeyeri, Performance evaluation of Egbin Thermal Power Station Nigeria, In: Proceedings of the World Congress on Engineering and Computer Science, 2011, San Francisco, USA.

[7] T.J. Kotas, The exergy method of thermal plant analysis, Butterworth, London, 1995.

[8] B.T. Lebele-Alawa, J.M. Asuo, Exergy analysis of Kolo Creek Gas Turbine Plant, Canadian Journal of Mechanical Science and Engineering 2 (2011) 172-184.

[9] I.S. Ertesvag, M.H. Kvamsdah, O. Bollard, Exergy analysis of a gas turbine combined cycle power plant with precombustion $\mathrm{CO}_{2}$ capture, Energy. 30(1) (2005) 5-39.

[10] B.C. Kwambai, Exergy analysis of Olkaria I Geothermal Power Plant, Kenya, A Report on the Geothermal Training Program, United Nation University, 2005. 
[11] G.P. Verkhiver, B.V. Kosoy, On the exergy analysis of power plants, Energy Conversion and Management. 42(18) (2001) 2053-2059.

[12] M. Anheden, Analysis of gas turbine systems for sustainable energy conversion, Ph.D. Thesis, Royal Institute of Technology, Sweden, 2002.

[13] U. Yildirim, A. Gungor, An application of exergoeconomic analysis for a CHP system, International Journal of Electrical Power \& Energy Systems. 42(1) (2012) 250-256.

[14] M.J. Ebadi, M. Gorgi-Bandy, Exergetic analysis of gas turbine plants, International Journal of Exergy. 2(1) (2005) 31-39.

[15] D. Sue, C. Chuang, Engineering design and exergy analysis of combustion gas turbine based power generation system, Energy. 29 (2002) 1183-1205.

[16] S. Adumene, Load-based Exergetic Assessment of an offshore thermal power plant in an equatorial environment, Studies in Engineering and Technology. 3(1) (2015) 19-27.

[17] S. Adumene, A.K. Le-ol, R.K.C. Amadi, Modeling Compressor's initial operating conditions effect on turbine performance in the tropical rainforest, American Journal of Engineering Research. 4(6) (2015) 80-88.

[18] M. Kanoglu, I. Dincer, M.A. Rosen, Understanding energy and exergy efficiencies for improved energy management in power plants, Energy Policy. 35(7) (2007) 3967-3978.

[19] B.T. Lebele-Alawa, V. Jo-Appah, Thermodynamic performance analysis of a gas turbine in an equatorial rain forest environment, Journal of Power and Energy Engineering, 3(01) (2015) 11-23.

[20] Y.A. Cengel, M.A. Boles, Thermodynamics - An engineering approach, $5^{\text {th }}$ Ed, McGraw-Hill Companies, New York, 2006.

[21] I. Dincer, Y.A. Cengel, Energy, Entropy and exergy concepts and their roles in thermal engineering, Entropy. 3(3) (2001) 116-149.

[22] K. Wark, D.E. Richard, Thermodynamics, $6^{\text {th }}$ Ed. McGraw-Hill Companies, USA, 1999.

[23] H.Y. Kwak, D.J. Kim, J.S. Joen, Exergetic and thermoeconomic analysis of power plants, Energy. 28(4) (2003) 343-360. 